\title{
$X$ and Millennial Employee Job Satisfaction Factor Study of Mongolia
}

\author{
Sugarsuren Enkhbaatar*, Battuvshin Gurbazar, Baasandash Choijil \\ Graduate School of Business, Mongolian University of Science and Technology, Ulaanbaatar, Mongolia \\ Email: *sugarsuren.en@gmail.com
}

How to cite this paper: Enkhbaatar, S., Gurbazar, B., \& Choijil, B. (2021). X and Millennial Employee Job Satisfaction Factor Study of Mongolia. Journal of Human Resource and Sustainability Studies, 9, 159-172.

https://doi.org/10.4236/jhrss.2021.92011

Received: March 17, 2021

Accepted: April 24, 2021

Published: April 27, 2021

Copyright $\odot 2021$ by author(s) and Scientific Research Publishing Inc. This work is licensed under the Creative Commons Attribution International License (CC BY 4.0).

http://creativecommons.org/licenses/by/4.0/

\begin{abstract}
Organizations have different approaches to attract and retain desired employees based on the company values, goals, and capacity. However, the turnover rate is increasing worldwide and Mongolia is not an exception. To succeed we should manage each employee individually. However, in real life companies do not have that capacity and resources. To manage more effectively, companies might need to group employees by their needs. Some research materials show that generations share similar values. Therefore, solution to that issue could be dividing employees by their birth generation. This paper aims to identify differences and similarities of $\mathrm{X}$ and Millennial generations job satisfaction factors of Mongolian employees. To effectively manage individual's need, questionnaire of this work was developed based on previous works on job satisfaction aspect, which distributed to 389 employees from Mongolia working in Mongolia, USA, Canada and Australia. The sorting criterion was affiliation to the generational cohort, Baby Boomers generation 2.8\%, Generation X 36\%, Generation Y 57.1\% and Generation Z 4.1\% respectively. Respondents geographical location: Ulaanbaatar (Capital of Mongolia) 68.1\%, Aimags (Rural areas of Mongolia) 27.5\% and abroad (USA, Canada, Australia) $4.4 \%$ respectively. This study reveals that employee engagement factor importance and reward program effectiveness differ by generations. Overall, company reputation, job security, benefits are rated differently by generations in regards to their importance level. Furthermore, generations prefer government award programs significantly different. The research results might serve companies and organizations to customize their program to attract and retain desired Mongolian employees based on their specific needs. To the best of the author's knowledge, there is no study conducted regards to job satisfaction and employee engagement factors of Mongolian employees by their generation.
\end{abstract}

\section{Keywords}

Job Satisfaction, Generation X, Millennial, Employee Engagement 


\section{Introduction}

Various research findings show that employees' values and characteristics differ by their generation (e.g. Berkup, 2014; Yu \& Miller, 2005; Ron et al., 1999). Job satisfaction is a very important part of an employee's lifecycle and motivation to remain loyal to an organization (Bathena, 2018). Therefore, it is important to understand how to make employees satisfied based on their values and needs.

In 2019, around 51.5\% of Mongolian population were aged from 25 - 56 (X and Millennial generation). However, there is no research material available on job satisfaction and employee engagement by generation in Mongolia. Therefore, it is crucial to identify job satisfaction factor differences and similarities of $\mathrm{X}$ and Millennials to attract and retain desired employees.

Objectives of this study are: To identify if there are differences on job satisfaction factors by generation; to identify the difference of $\mathrm{X}$ and Millennial generation on job engagement; to explore how Xers and Millennials feel towards different types of rewards and management approach.

Literature review was conducted on similar research works to deeply understand basis of job satisfaction factors and generation values and differences; and to identify effective methodology to conduct analysis. After that questionnaire was developed in regards to job satisfaction and employee engagement ratings and distributed to Mongolian employees aged from 18 - 75. Significance testing was conducted on the collected data. Then statistical analyses have been carried out to identify differences of $\mathrm{X}$ and Millinial generations perspective. Descriptive method was used to determine connection between previous research materials and current study findings to achieve objectives.

\section{Literature Review}

Studies on the topic are available in both Western and Asian countries, but most are in the United States and East Asia. In these studies, it has been observed that there is considerable evidence that the characteristics of the generations differ from each other. In line with this, there is a need for a different management approach. Some certain conditions and factors increase the satisfaction of generation. Their effects vary and sometimes coexist. Satisfaction is related to human values, and values vary from person to person and tend to be common by generations.

The history of the theory of generation is divided into two main approaches. Many social scientists support the theory of "imprint hypothesis" (Hans Jaeger).

The main representatives of the theory of twentieth-century generation studies are Pierre Bourdieu, José Ortega and Gasset, Julius Peterson, Wilhelm Pinder, and Julian Marias as well as Carl Mannheim (Codrington, Detailed Introduction to Generational Theory, 2008).

The application of this theory to countries takes into account the influence of major social factors, such as wars and riots. Such global events affect the psy- 
chology of people and societies as a whole (Codrington, Detailed Introduction to Generational Theory, 2008).

\subsection{Baby Boomers}

Baby Boomers (BB) workers prefer stable employment and are more diligent than other generations (Loomis, 2000).

In a study of the "X" generation, David Rat found that the older generation was more loyal to their employers and more willing to work with others. Carp. $\mathrm{X}$ and Fuller. $\mathrm{K}$ also reflected this trait in their books on the Great Generation and the Generation X (Tolbize, Generational Differences in the Workplace, 2008).

This generation is not technologically advanced and, in general, doesn't like change (Yu \& Miller, 2005). They are defined as being positive, good, liberal in listening to new ideas and opinions, and tending to avoid conflict (Ron et al., 1999).

In terms of management, some experts have suggested that a task-oriented approach is more appropriate (McGregor, 1968).

\subsection{Generation}

Some scholars have identified the $\mathrm{X}$ generation, which makes up a large percentage of the current workforce, as self-sufficient, self-satisfied, and not only diligent but also highly valued (Yu \& Miller, 2005).

In the 1990s, there was a great crisis. Therefore, this generation has experienced unemployment and social imbalances (Kalela et al., 2001). One of the features of this generation is that job satisfaction is more important than promotion. It is believed that how this generation is managed creates a need to be different from the previous generation, who are different in terms of education and skills (Tulgan, 1995).

The employees of this generation are technologically advanced and results-oriented (Crampton \& Hodge, 2006). Joyner's 2000 study found that it was more important for Generation X to feel that they had completed a task than to complete it on time (Tolbize, Generational Differences in the Workplace, 2008).

According to Carp, this generation of workers may not be motivated by money, but if money or wages are insufficient, they tend to become inactive (Hank Karp, 2002). In other words, money alone is not enough to keep them motivated, but it is important to keep their productivity.

Because of their high level of technological knowledge, they have developed a tendency to perform work independently with the help of technology (Dogan Gursoy, 2008).

\subsection{Y Generation}

According to the Australian Center for Experimental Training, Generation $\mathrm{Y}$ is 
ambitious, hardworking, ready for change, technologically savvy, and forward-thinking. This generation wants to get a lot in a short time. Employees of the Y generation prefer high salaries, constant challenges, wealth, and diverse jobs (Treuren \& Kathryn, 2010).

Loyalty to one employer is not the main thing to employees of this generation, and it is common to move from one job to another (Treuren \& Kathryn, 2010).

Some researchers point out that this generation prefers informal simplicity in their work and wants their managers to consider and care about their well-being (Dogan Gursoy, 2008).

Researchers suggest that the generation that grew up under the influence of technological advances around the world has acquired the ability to quickly access information with the help of technology, extensive knowledge, and the ability to perform many tasks simultaneously (Dogan Gursoy, 2008).

According to researchers, the millennials have a completely different mentality than their predecessors (Hershatter \& Epstein, 2010).

Researchers believe that this generation is well-versed in the ability to do many tasks at once, filter out distractions, and retrieve information quickly (Tapscott, 2008).

Emphasis is placed on work-life balance (Altizer, 2010). Some employers and managers see this as a sign of selfishness, leading to the conclusion that "the younger generation is lazy and overly self-centered". But it could also be a catalyst for a change in attitudes toward work and a more humane workplace environment, according to Harvard Business Review (Hewlett et al., 2009).

It may be helpful for managers to have an open relationship with this generation to prove their job security (Myers \& Sadaghiani, 2010).

\subsection{Z Generation}

According to the Institute for Emerging Issues, the $\mathrm{Z}$ generation is the ethnically richest and most technologically advanced generation (NCSU, 2011).

They are considered to be innovative, trustworthy, patient, and less likely to be money-makers (Schawbel, 2014).

Generation $\mathrm{Z}$ values include transparency, flexibility, and individual freedom. Some publishers have suggested that these are ethical requirements that, if not met, can lead to frustration among employees, reduced productivity, and lower engagement (Bascha, 2011).

This generation is interested in working under the leadership of a loyal and honest person (Shilpa Gaidhani, 2019).

\subsection{Job Satisfaction}

Job Satisfaction affects ability to perform a task productively and consistently. The concept of job satisfaction is considered to be a multifaceted psychological response and consists of three concepts: cognition, influence, and behavior (Weiss, 2002). Locke's range of affect theory (Wu \& Yao, 2006), the dispositional 
approach (Judge, 1998), The Job Characteristics Model (Oldham, 1976), Equity Theories (Pritchard, 1969) are used for this study to develop questionnaire.

Beyond that employee engagement studies are used to understand how engagement factors can have an effect on job satisfaction of employees. For instance, according to Officevibe Content Team workload, benefits, clarity of role and expectations, office environment, salary are the areas that need to be focused on to improve engagement of employees (Officevibe Content Team, 2017).

The thorough analysis of the literature allows to conclude that job satisfaction has a strong impact on employee performance and retention. Various factors have an effect on job satisfaction and it can vary depending on employees' generation. Various study findings show that employees from same generation share similar values. Therefore to effectively manage employees it is important to understand what makes them satisfied.

Based on literature review following hypothesis are developed:

$\mathrm{H1}$ : Factors of job satisfaction differ by generations.

$\mathrm{H} 2$ : Engagement and reward program preferences differ by generations.

Research hypothesis is checked by quantitative statistical method. First, to test the variable significance Cronbach's Alpha used, then KMO and Bartlett's test was used to check sampling adequacy. After that One-Way-Anova was used to determine whether there is statistical evidence that the associated factor means are significantly different.

The following section outlines methodology of this study.

\section{Methodology}

\subsection{Research Design}

The study used questionnaire to identify important factors influencing job satisfaction of different generations. There were two rounds of survey conducted to achieve final outcome. The first survey focused on identifying key factors influencing job satisfaction, management practices, and job expectations. A standard closed end questionnaire survey was developed to achieve results based on available literature on job satisfaction. Based on available research studies widely used, statistically or empirically proven to be effective questions were chosen to be included in the survey. Questionnaire designed to have confidentiality and data was not analyzed at individual level. Unrealistic or hypothetical scenarios and leading questionnaire items were avoided.

In the second phase (see Table 1) the Rosenberg self-esteem scale (RSES) developed by sociologist Morris Rosenberg was used to collect the data needed to test the study hypotheses. The questionnaire from the first round of survey was extended by using available research materials on job satisfaction. The questionnaires were graded on a scale of $1-3,1-4$ and $1-5$. The dichotomous questions that have Yes/No answers are also used. 
Table 1. Survey design overview.

\begin{tabular}{ccc}
\hline \multirow{2}{*}{ Question numbers } & \multicolumn{2}{c}{ Description } \\
\cline { 2 - 3 } & Question description & Number of questions \\
\hline S11 - S18 & Factor importance ratings on Job Safisfaction & 8 \\
S21 - S213 & Factor ratings on Job Satisfaction & 13 \\
E11 - E19 & Engagement factor ratings & 19 \\
H31 - H35 & Reward programs ratings & 5 \\
H61 - H69 & Management approach ratings & 9 \\
\hline
\end{tabular}

The questionnaire for survey among employees consisted of three sections. The first section was regarding demographics of respondents on their age, gender, geographical location. The second section covered questions concerning job satisfaction factors perception. The final section included questions regarding employee engagement related factors as well as manager's approach, which has strong impact on job satisfaction.

\subsection{Sample and Data Collection}

The research sample of survey consisted of 316 and 389 respondents, first and second round respectively. All respondents were from Mongolia working in Mongolia, USA, Canada and Australia. There were 1.1 million Mongolians were employed by Quarter 4, 2020 (Statistical Information Data Base, 2020). Following equation for determining sample size were used, with confidence level of sample size $95 \%$ and Confidence interval 5\%.

$$
\text { Sample size }=\frac{(\text { Zscore }) 2 \times \operatorname{StdDevx}(1-\operatorname{StdDev})}{(\text { margin of error }) 2}=\frac{(1.96) 2 \times 0.5(1-0.5)}{(0.05) 2}=384.1
$$

The results of the second round of questionnaire used for data analysis. The sorting criterion was affiliation to the generational cohort, Baby Boomers generation $2.8 \%$, Generation X 36\%. Generation Y $57.1 \%$ and Generation Z $4.1 \%$ respectively. Respondents geographical location: Ulaanbaatar (Capital of Mongolia) $68.1 \%$, Aimags (Rural areas of Mongolia) $27.5 \%$ and abroad (USA, Canada, Australia) $4.4 \%$ respectively. $99.7 \%$ of respondents had higher education level.

\subsection{Data Analysis}

For statistical processing of the obtained data, we chose the procedures that corresponded to the interpretation plan. Initial data processing included the calculation of significant values from descriptive statistics, mainly the arithmetic means, standard deviation, analysis of variance and mean error. Data processing was performed using SPSS statistical software. First, Cronbach's Alpha tested for variables (see Table 2).

KMO and Bartlett's test used to check sampling adequacy (0.943) and concluded sampling is adequate (see Table 3 ). 
Table 2. Cronbach alpha test.

\begin{tabular}{lccccc}
\hline \multirow{2}{*}{ Reliability Statistics } & \multicolumn{5}{c}{ Questions } \\
\cline { 2 - 6 } & S11 - S18 & S21 - S213 & E11 - E19 & H31 - H35 & H61 - H69 \\
\hline Cronbach's Alpha & 0.957 & 0.971 & 0.785 & 0.677 & 0.863 \\
\hline
\end{tabular}

Table 3. KMO and Bartlett's test.

\begin{tabular}{cc}
\hline \multicolumn{2}{c}{ KMO and Bartlett's Test } \\
\hline Sampling Adequacy & 0.943 \\
Sig. & 0.000 \\
\hline
\end{tabular}

\section{Findings and Discussion}

\section{Generation Differences}

To test the hypothesis following quantitative methods have been used. One-Way ANOVA is used to compare the means of generations in order to determine whether there is statistical evidence that the associated factors means are significantly different (see Table 4). E14 (Engagement factor rating question) about how important is company's reputation for employee engagement $Z$ generation respondents answered least important $($ mean $=2.00)$, Y generation respondents answered important (mean $=2.34)$, $\mathrm{X}$ generation respondents answered important $($ mean $=2.42)$, and Baby Boomers answered somehow important $($ mean $=$ 2.27). Therefore, there is statistical evidence that the associated population means are significantly different $p=0.070(10 \%)$.

Then, E16 (Engagement factor rating question) question about importance of job security on employee engagement, generation $\mathrm{X}$ and $\mathrm{Y}$ responded that is important (mean $=2.73$ and mean $=2.76$ ) and $\mathrm{Z}$ and $\mathrm{BB}$ generations responded that it is somehow important (mean $=2.37$ and mean $=2.63)$. That means job security importance differs by generations $(p=0.030)$. E19, question regards to importance of benefits $\mathrm{X}$ and $\mathrm{Y}$ responded similarly (mean $=2.59$, mean $=2.60$ ). There is a statistical difference between means of responses $(p=0.057)$.

H34-How effective is government/industry awards, question regards to reward effectiveness, BB generation responded that it is a very effective type of reward (mean $=2.90)$, in contrast younger the generation gets this type of reward becomes least effective $(p=0.50)$.

H65-How suitable is the job allocation by your supervisor, question regards to management $\mathrm{Z}$ generation respondents answered it is suitable (mean $=1.81$ ), which was highest of all generations and lowest rates are from $\mathrm{X}$ generation (mean $=1.56)$. H66, question regarding opportunity of development of new skills, older the generation gets there are less opportunity to develop new skills $(\mathrm{BB}$ mean $=1.45)$ and younger the employees get they responded that they have opportunity to develop new skills $(\mathrm{Z}$ mean $=1.81)$. 
Table 4. One-way Anova results.

\begin{tabular}{|c|c|c|c|c|}
\hline \multirow{2}{*}{ Question } & \multicolumn{3}{|c|}{ Anova results } & \multirow{2}{*}{ Mean } \\
\hline & Question & Sig. & Generations & \\
\hline \multirow{4}{*}{ E14 } & \multirow{4}{*}{$\begin{array}{c}\text { How important is company reputation } \\
\text { for employee engagement }\end{array}$} & \multirow{4}{*}{0.075} & $\mathrm{Z}$ & 2.00 \\
\hline & & & $\mathrm{Y}$ & 2.34 \\
\hline & & & $\mathrm{X}$ & 2.42 \\
\hline & & & BB & 2.27 \\
\hline \multirow{4}{*}{ E16 } & \multirow{4}{*}{$\begin{array}{l}\text { How important is job security for } \\
\text { employee engagement }\end{array}$} & \multirow{4}{*}{0.030} & $\mathrm{Z}$ & 2.37 \\
\hline & & & $\mathrm{Y}$ & 2.73 \\
\hline & & & $\mathrm{X}$ & 2,76 \\
\hline & & & $\mathrm{BB}$ & 2.63 \\
\hline \multirow{4}{*}{ E19 } & \multirow{4}{*}{$\begin{array}{l}\text { How important are benefits for } \\
\text { employee engagement }\end{array}$} & \multirow{4}{*}{0.057} & $\mathrm{Z}$ & 2.43 \\
\hline & & & $\mathrm{Y}$ & 2.59 \\
\hline & & & $\mathrm{X}$ & 2.60 \\
\hline & & & $\mathrm{BB}$ & 2.18 \\
\hline \multirow{4}{*}{$\mathrm{H} 34$} & \multirow{4}{*}{$\begin{array}{l}\text { How effective is government/industry } \\
\text { awards }\end{array}$} & \multirow{4}{*}{0.050} & $\mathrm{Z}$ & 2.12 \\
\hline & & & $\mathrm{Y}$ & 2.69 \\
\hline & & & $\mathrm{X}$ & 2.69 \\
\hline & & & BB & 2.90 \\
\hline \multirow{4}{*}{ H65 } & \multirow{4}{*}{$\begin{array}{l}\text { How suitable is the job allocation } \\
\text { by your supervisor }\end{array}$} & \multirow{4}{*}{0.068} & $\mathrm{Z}$ & 1.81 \\
\hline & & & $\mathrm{Y}$ & 1.68 \\
\hline & & & $\mathrm{X}$ & 1.56 \\
\hline & & & BB & 1.63 \\
\hline \multirow{4}{*}{ H66 } & \multirow{4}{*}{$\begin{array}{l}\text { Do you get opportunity to } \\
\text { develop/learn new skills }\end{array}$} & \multirow{4}{*}{0.089} & $\mathrm{Z}$ & 1.81 \\
\hline & & & $\mathrm{Y}$ & 1.59 \\
\hline & & & $\mathrm{X}$ & 1.52 \\
\hline & & & BB & 1.45 \\
\hline
\end{tabular}

Satisfaction (S11 - S213) related factors did not prove to be statistically different $(p<0.177)$.

Figure 1 shows importance of company's reputation by generation perspectives. Some respondents from X, Y, Z generations responded that company's reputation has low importance level, 7\%, 9\%, 19\% respectively. In contrast, Baby Boomers responded that company's reputation is overall important for them ( $0 \%$ responded low). This could be due to younger generations tend to be not so loyal to the employers and if needed for them it is normal to change many jobs. 
Figure 2 beneath illustrates how important is job security for respondents. For $\mathrm{X}, \mathrm{Y}$ generations this factor is highly important, $78 \%$ and $76 \%$ respectively. This could be due to the fact that $\mathrm{X}$ generation has experienced unemployment and social imbalances because of great crisis in 1990s. Therefore, it is possible that they tend to seek job security. As for Y generation this could be because they want their managers to consider and care about their well-being (Dogan Gursoy, 2008), which covers their job security.

Results regards to importance of benefits in general shown in Figure 3. Importance of benefits are same for $\mathrm{X}$ and $\mathrm{Y}$ generation as per below graph. Interestingly for Baby boomers benefits are not so important for job satisfaction. Only $18 \%$ of BBs responded that this factor is highly important.

This can be due to the fact that Baby Boomers respect their employer more than other generations do. Therefore, respect factor might have an effect on benefit needs. As for younger generations this factor is important. According to previous researchers younger generation believe fair compensation for their work is crucial. Therefore, importance of benefits for $\mathrm{X}, \mathrm{Y}, \mathrm{Z}$ generations is expected to be high.

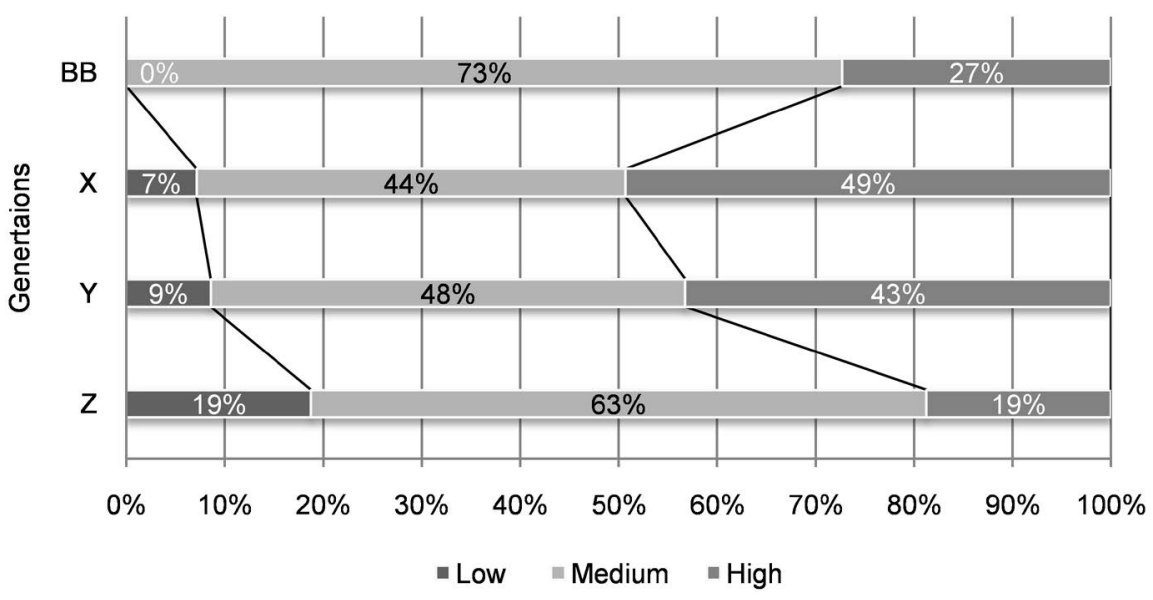

Figure 1. Importance of company reputation.

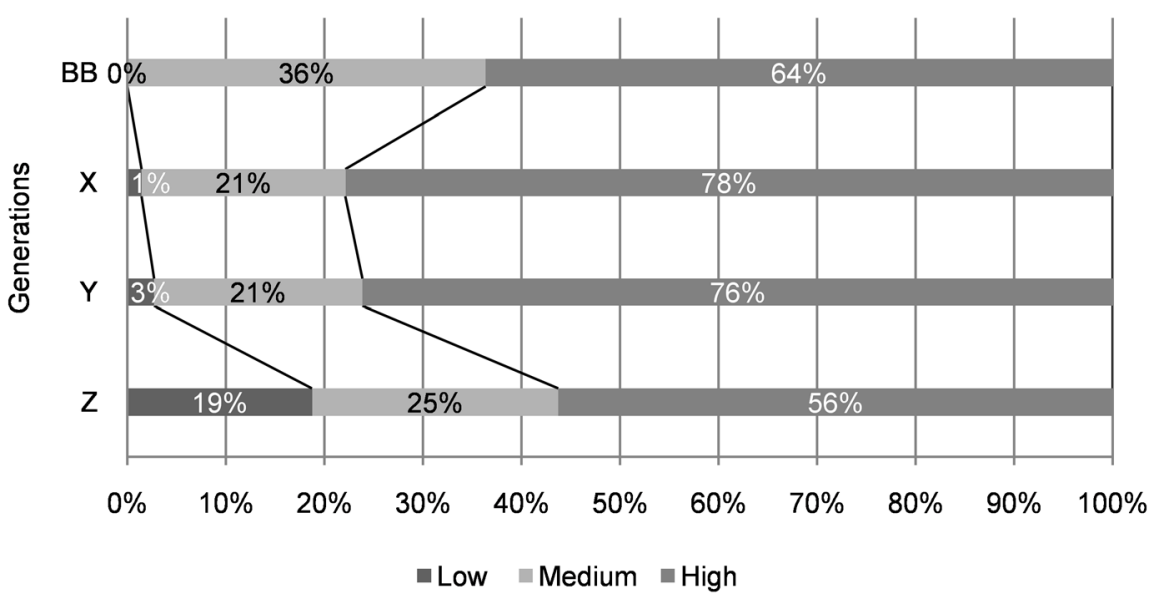

Figure 2. Importance of job security. 


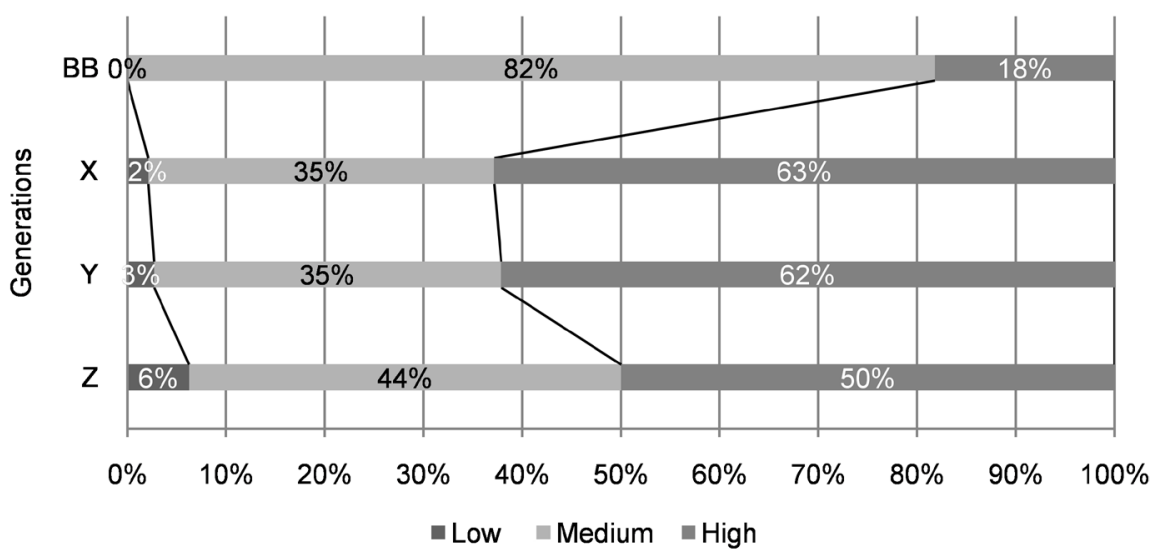

Figure 3. Importance of benefits.

Figure 4 shows ratings on effectiveness of government/industry awards. As per results, younger the generation gets percentage of "no effect" regards to government/industry awards increases. In other words, young generation of employees does not favor government awards as an effective reward.

Same pattern applies to "low effect" criteria. This can be due to younger generations tend to require more work-life balance reward programs rather than government appreciation. In addition, this can be explained as $\mathrm{X}$, Y generations are technological savvy and social media is part of their daily life. Therefore, comparing to previous generation they do not need government/industry awards to show their success to the public, instead if they want they will simply post their achievement on social media platform to satisfy their relatedness need.

Job allocation effectiveness and if it is fair or not is an important factor for being satisfied at work. Interestingly, this study shows that generations have different perspective regards to their managers/supervisors job allocation approach (see Figure 5).

$44 \%$ of $\mathrm{Y}$ generation answered that the job allocation by their supervisors is not effective, followed by X generation 32\% (Figure 5). This trend can be explained by other studies findings about generation perspectives. For instance, $\mathrm{X}$ and $\mathrm{Y}$ generations are more loyal to their supervisors rather than company itself. Which might increase importance of their managers approach towards the work allocation and this factor can be more crucial for them. Therefore, Xers and Yers might give more attention to this factor.

Figure 6 illustrates opportunity regards to development of new skills. As expected older the employees get there are less opportunity for them to develop new skills. (BB 55\%, X 48\%). Employers tend to train new, younger employees more. As a result older generation of employees gets less opportunity to develop new skills.

It is important to provide training opportunity to all generations equally. This finding shows that older generations have less chance to update their knowledge and learn new skills. However, having right skills could increase engagement as well as job satisfaction. 


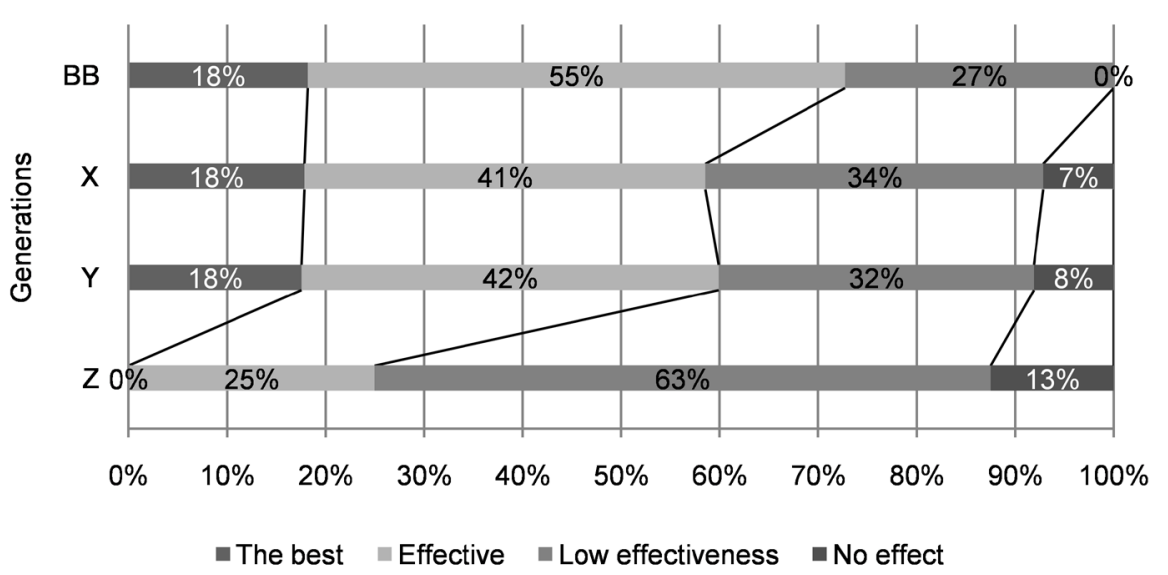

Figure 4. Effectiveness of government/industry awards.

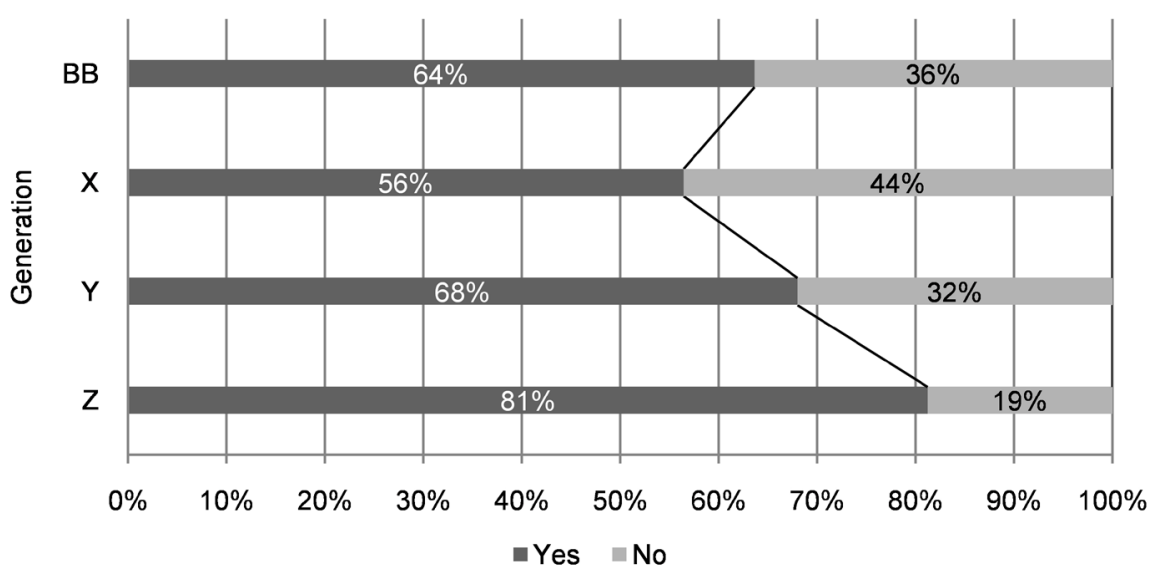

Figure 5. Effectiveness of job allocation by supervisors.

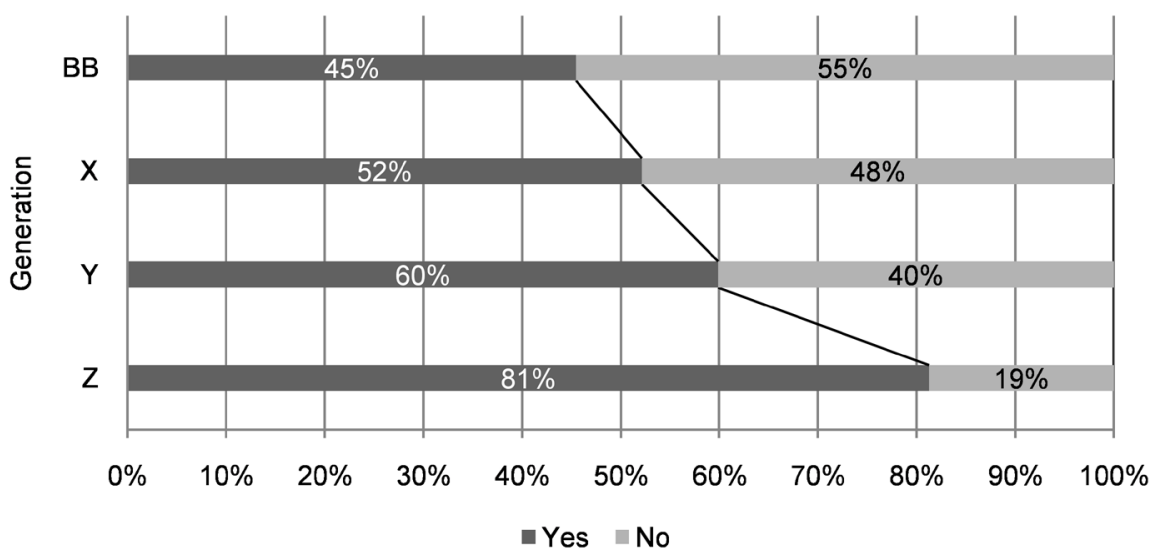

Figure 6. Availability of opportunity to develop new skills.

\section{Conclusion}

The purpose of this study was to identify if there are differences on job satisfaction factors by generation; to identify the difference of $\mathrm{X}$ and Millennial generation on job engagement; to explore how Xers and Millennials feel towards different types of rewards and management approach. 
Nowadays, it is common to not retire at the retirement age. Also, it is normal to start working at young age to get more experience. As a result, there are few different generations in job market actively participating. Therefore, it is becoming crucial and challenging for companies to find right approach to satisfy different needs.

H1: Factors of job satisfaction differ by generations are rejected and there were no significant differences observed $(p<0.177)$. However, this does not mean that generations perceive all job satisfaction factors similarly. In future, more in deep research on job satisfaction and generation needs to be conducted to shed the light for employers to understand needs of different generation employees.

$\mathrm{H} 2$ : Engagement and reward program preferences differ by generations is accepted $(p>0.089)$. This means engagement factors and reward programs are rated differently by Baby boomers, $\mathrm{X}$, Millennials and $\mathrm{Z}$ generations. When companies develop their programs to attract and engage their employees it is suggested to take an account of these factor differences in order to achieve better outcomes.

The insight gained may serve Mongolian companies as well as companies with Mongolian employees to align some of their programs to adapt specific needs of those generations. To do that following steps can be followed to achieve desired result: conduct survey within employees, analyze the results based on employees generation, develop few different programs based on specific group needs, ask employees to choose from those programs or include more actions which will satisfy desired part of company employees (ex. if company wants Xers to be more engaged, develop more actions which will help to address that generation needs), evaluate and revise the program as required.

\section{Limitations}

The sample was limited to Mongolian employees solely with random sampling. Future researchers might increase number of participants to increase significance of the survey results. Furthermore, selection of factors could be expanded in number to determine if other factors not included in this study have an effect on job satisfaction of generations and if those factors differ.

\section{Conflicts of Interest}

The authors declare no conflicts of interest regarding the publication of this paper.

\section{References}

Altizer, T. E. (2010). Motivating Gen Y Amidst Global Economic Uncertainty. The Journal of Learning in Higher Education, 6, 37-45.

Bascha (2011). Z: The Open Source Generation.

https://opensource.com/business/11/9/z-open-source-generation 
Bathena, Z. (2018). Why Job Satisfaction Is an Important Phenomenon of the Vicious Circle? https://www.entrepreneur.com/article/310608

Berkup, S. B. (2014). Working with Generations X and Y in Generation Z Period. Mediterranean Journal of Social Sciences, 5, 218-229. https://doi.org/10.5901/mjss.2014.v5n19p218

Codrington, G. (2008). Detailed Introduction to Generational Theory. 2-15.

Crampton, S. M., \& Hodge, J. W. (2006). The Supervisor and Generational Differences. Allied Academies International Conference. Academy of Organizational Culture, Communications and Conflict, 11, 19-22.

Dogan Gursoy, T. A. (2008). Generational Differences: An Examination of Work Values and Generational Gaps in the Hospitality Workforce. International Journal of Hospitality Management, 27, 448-458.

Hank Karp, C. F. (2002). Bridging the Boomer-Xer Gap: Creating Authentic Teams for High Performance at Work. Boston, MA: Nicholas Brealey Publishing.

Hershatter, A., \& Epstein, M. (2010). Millennials and the World of Work: An Organization and Management Perspective. Journal of Business and Psychology, 25, 211-223. https://doi.org/10.1007/s10869-010-9160-y

Hewlett, S. A., Sherbin, L., \& Sumberg, K. (2009). How Gen Y \& Boomers Will Reshape Your Agenda. Harvard Business Review https://hbr.org/2009/07/how-gen-y-boomers-will-reshape-your-agenda

Judge, T. A. (1998). Dispositional Effects on Job and Life Satisfaction. Journal of Applied Psychology, 83, 17-34. https://doi.org/10.1037/0021-9010.83.1.17

Kalela, J., Kiander, J., Kivikuru, U, Loikkanen, H. A., \& Simpura, J. (2001). Down from the Heavens, Up from the Ashes. Government Institute for Economic Research. https://www.doria.fi/bitstream/handle/10024/148630/j27-6.pdf?sequence=1\&isAllowed $=\mathrm{y}$

Loomis, J. E. (2000). Generation X. https://roughnotes.com/rnmagazine/2000/sept00/09p52.htm

McGregor, D. (1968). Leadership and Motivation. Cambridge, MA: MIT Press.

Myers, K. K., \& Sadaghiani, K. (2010). Millennials in the Workplace: A Communication Perspective on Millennials' Organizational Relationships and Performance. Journal of Business and Psychology, 25, 225-238. https://doi.org/10.1007/s10869-010-9172-7

NCSU (North Carolina State University) (2011). Generation Z Initiatives. https://iei.ncsu.edu/generation-z-initiatives/

Officevibe Content Team (2017). 10 Shocking Statistics about Disengaged Employees. https://officevibe.com/blog/disengaged-employees-infographic

Oldham, G. R. (1976). Conditions under Which Employees Respond Positively to Enriched Work. Journal of Applied Psychology, 61, 395-403.

https://doi.org/10.1037/0021-9010.61.4.395

Pritchard, R. D. (1969). Equity Theory: A Review and Critique. Organizational Behavior and Human Performance, 4, 176-211.

Ron, Z., Claire, R., \& Filipczak, B. (1999). Generations at Work: Managing the Clash of Veterans, Boomers, Xers, Nexters in Your Workplace. New York, NY: AMACOM.

Schawbel, D. (2014). Gen Z Employees: The 5 Attributes You Need to Know. https://www.entrepreneur.com/article/236560

Shilpa Gaidhani, L. A. (2019). Understanding the Attitude of Generation Z towards Workplace. International Journal of Management, Technology and Engineering, 9, 
2804-2812.

Statistical Information Data Base (2020). Ажиллагчид. Улаанбаатар: Статистикийн мэдээллийн нэгдсэн сан.

Tapscott, D. (2008). How Digital Technology Has Changed the Brain.

https://www.bloomberg.com/news/articles/2008-11-10/how-digital-technology-has-cha nged-the-brainbusinessweek-business-news-stock-market-and-financial-advice

Tolbize, A. (2008). Generational Differences in the Workplace. Minneapolis, MN: Research and Training Center on Community Living.

Treuren, G., \& Kathryn, A. (2010). The Employment Expectations of Different Age Cohorts: Is Generation Y Really That Different? Australian Journal of Career Development, 19, 49-61. https://doi.org/10.1177/103841621001900207

Tulgan, B. (1995). Managing Generation X: How to Bring Out the Best in Young Talent. Aberdeen, WA: Silver Lake Publishing.

Weiss, H. M. (2002). Deconstructing Job Satisfaction. Human Resource Management Review, 13, 173-194.

Wu, C. H., \& Yao, G. (2006). A Perspective from Locke's Range-of-Affect Hypothesis. Social Indicators Research, 79, 485-502. https://doi.org/10.1007/s11205-005-5666-5

Yu, H., \& Miller, P. (2005). Leadership Style: The X Generation and Baby Boomers Compared in Different Cultural Contexts. Leadership and Organization Development Journal, 26, 35-50. https://doi.org/10.1108/01437730510575570 